\title{
Potential of transplanting bare-root seedlings comparing with direct seeding in some Egyptian cotton cultivars
}

\section{Houda A. Rabeh}

Agronomy Department, Faculty of Agriculture, Cairo University, Giza, Egypt. Corresponding author e-mail address: hodamarzook@agr.cu.edu.eg

DOI: 10.21608/jalexu.2021.99864.1015

\section{Article Information}

Received:October $6^{\text {th }} 2021$

Revised: October $20^{\text {th }}$ 2021

Accepted:November $10^{\text {th }}$ 2021

Published:November $14^{\text {th }}$ 2021
ABSTRACT: Limitation of cultivated area and shortage of irrigation

water are mainly challenges of Egyptian agriculture. One of the possible solutions to improve the utilization efficiency of cultivated land, increase cotton cultivation area and guarantee the harvest of extra cutting from Egyptian clover is cotton transplanting. Therefore, this study aimed to evaluate the possibility of transplanting seedlings comparing with direct seeding methods and their effect on growth, yield and fiber quality for cotton cultivars Giza 92, Giza 94 and Giza 95. Two field experiments were conducted in Agricultural Research and Experimental Station, Faculty of Agriculture, Cairo University, Giza, Egypt during 2019 and 2020 seasons. The experiments were laid out in a split-plot based on a Randomized Complete Block Design with three replicates. A significant effect of transplanting seedlings compared with direct seeding, which increased plant height $(10.46 \%)$, sympodial branches per plant $(5.54 \%)$ and decreased $1^{\text {st }}$ sympodial node position $(14.17 \%)$, on the other hand, decreased open bolls per plant $(7.04 \%)$, boll weight $(2.90 \%)$, seed index $(6.57 \%)$, seed cotton yield per plant $(5.98 \%)$ and per feddan $(6.79 \%)$ and most studied cotton fiber quality parameters; however, insignificant effect on total bolls per plant, lint percentage, fiber length and elongation. Cotton cultivars recorded significant differences in most studied parameters, Whereas, Giza 95 as showed superiority in yield and yield components, while Giza 92 and Giza 94 in fiber quality parameters. We need more researches for suitable germination growth medium, age of transplanting seedlings and economic feasibility to recommend transplanting as an alternative to direct seeding.

Keywords: Cotton, Gossypium barbadense L., transplanting, growth parameters, cultivars, fiber quality.

\section{INTRODUCTION}

Egyptian cotton cultivars are classified globally as a high-quality fiber (extra-long and long staple). Despite this, we find the cotton cultivated area $(65,000$ ha in $2020 / 21$ according to USDA, 2021) is limited for various reasons, including the limitation of total agricultural land area and irrigation water in Egypt, at the same time, feed crops such as Egyptian clover, as well as grain crops such as wheat can precede cotton planting. Therefore, transplanting allows the farmers to harvest wheat crop in proper time and obtain extra cutting from Egyptian clover before planting cotton which contribute to solve shortage of feed crops and increase cotton cultivation area.

Generally, little studies have been conducted to improve the utilization efficiency of cultivated area by enhancing cotton productivity using transplanting seedlings. Previous studies cleared different trends in the effect of transplanting seedling cotton plants on growth, productivity and fiber quality compared with direct seeding. Many researchers found that transplanted cotton profitable because it maintains optimum plant population and a greater number of bolls per unit area. Similarly, advantages of transplanted cotton relative to increase seed cotton and lint yield have been found in other cotton-growing countries (Karve, 2003; Dong et al., 2007 and Akbar et al., 2015). Transplanting seedlings enhance soil Nbalance, less depletion of $\mathrm{P}$ and $\mathrm{K}$ for plants and improved the cotton productivity by $14.2 \%$ over direct seeding (Rajpoot et al., 2016 and Ahmad et al., 2018). Seif-El-Nasr et al. (1996) showed that transplantation, not only reduces the use of fertilizer, but also increases the yield compared to direct seed planting and also transplanting after wheat harvest. Also, Leskovar et al. (2021) showed significant and consistent improvements in root and shoot traits, and yield for transplants as compared to direct seeded plants.

On the other hand, many researchers found that cotton transplanting gave lower yield and fiber quality than direct seeding method. In Egypt, Cotton transplanting experiments using bare-root transplanting (BRT) was the earliest documented at Assiut University by Bakheit (1965). His results indicated that BRT plants flowered and matured much later and were heavily affected by boll weevils than directly seeded cotton, resulting in significantly lower yield and its components, which yielded only $20-57 \%$ that of directly sown cotton. Abdel-Ghaffar et al. (1976) and Radwan (1988) reported that the transplanting 
cotton seedlings with bare roots usually yielded less than direct seeding this due to the damages usually happens to the root system during transplanting process. Hamed (1995), Dwedar (1998) and Ismail et al. (2000) all came to the conclusion that seed-cotton yield of direct seeded cotton was higher than transplanted cotton plants. Also, adoption of the transplanting technique is regarded expensive to farmers compared to the market price of seed-cotton (Kamel et al., 1991). In India, Karve (2003) reported that the BRT plants failed to survive after transplanting. Moreover, cotton transplantation after barley harvest, gave cotton yield same as direct seed plantation (Choi et al., 1992). Delay in transplantation reduce the number of bolls and boll weight (Jahromi and Mahboubi, 2012). High plant population has been found to give higher plant height, lower number of branches per plant and reduced boll weight (Wali and Koraddi, 1989). The main objective of this study is to investigate the effect of transplanting bare-root seedlings on cotton plant growth, yield and its components and fiber quality comparing with direct seeding method.

\section{MATERIALS AND METHODS Field experiment}

Field experiments were carried out in Agricultural Research and Experimental Station, Faculty of Agriculture, Cairo University, Giza, Egypt ( $\left.31^{\circ} 11^{\prime} 33.43^{\prime} \mathrm{E}, 30^{\circ} 1^{\prime} 36.16^{\prime} \mathrm{N}\right)$ during two successive summer seasons (2019 and 2020) to evaluate the possibility of transplanting cotton plants to improve the utilization efficiency of cultivated land and guarantee the harvest of extra cutting from Egyptian clover (Trifolium alexandrinum L.) before planting cotton.

The experiments were laid out in a splitplot based on a Randomized Complete Block Design (RCBD) with three replicates. Treatments included two planting methods (direct seeding and transplanting bare-root) in main plots and three cotton cultivates (Giza 92 extra-long staple and Giza 94 long staple grown at lower Egypt, and Giza 95 long staple grown at upper Egypt) were applied in sub-plots. Each plot (experimental unit) had six ridges, each of $0.6 \mathrm{~m}$ in width and $4.0 \mathrm{~m}$ in length, occupying an area of $14.4 \mathrm{~m}^{2}$. The preceding crop was Egyptian clover. In the direct seeding methods, seeds were planted on the first week of April in both seasons in ridges with hills $20 \mathrm{~cm}$ apart. Seeds were sowen in nursery at the same time of direct seeding in both seasons, after 4 weeks (seedlings achieve 3-4 leaves), seedlings were pulled in presence of water and two healthy seedlings were transplanted within less than one hour in the permanent field plots in hills $20 \mathrm{~cm}$ apart on the ridge. Transplanted seedling plots were irrigated every week after transplanting for three times. Nitrogen at a level of $60 \mathrm{~kg} \mathrm{~N} \mathrm{fed}^{-1}$ as ammonium sulfate $(20.5 \% \mathrm{~N})$, potassium at $48 \mathrm{~kg}$ $\mathrm{K}_{2} \mathrm{O}$ fed $^{-1}$ as potassium sulphate $\left(48 \% \quad \mathrm{~K}_{2} \mathrm{O}\right)$ and Phosphorus at $30 \mathrm{~kg} \mathrm{P}_{2} \mathrm{O}_{5} \mathrm{fed}^{-1}$ as calcium super phosphate $\left(15.5 \% \quad \mathrm{P}_{2} \mathrm{O}_{5}\right)$ were applied. The other agricultural practices were carried out according to the usual practices in the cotton fields. The harvesting was performed two times on the second and fourth weeks of September in both seasons.

\section{Soil analysis}

A composite soil samples were collected from $0-30,30-60$ and $60-90 \mathrm{~cm}$ depth during the study years before planting and were prepared for analyses in laboratory. The particle size distribution, $\mathrm{pH}, \mathrm{EC}$, total $\mathrm{CaCO}_{3}$, organic matter $(\mathrm{OM})$, total and available nitrogen $(\mathrm{N})$, Phosphorus (P), Potassium (K) according to standard methods outlined by Jackson (1973) and Keeney and Nelson (1982). Details of soil analysis are given in (Table $1)$.

\section{Collection of experimental data \\ Growth parameters}

Plant height $(\mathrm{cm})$ and position of $1^{\text {st }}$ sympodial node were recorded on ten random plants taken from two ridges of each experimental plot at 120 days after sowing (DAS).

\section{Yield and yield components}

Ten guarded plants were taken at random from each plot to determine, number of sympodial branches per plant, number of total and open bolls per plant, boll weight $(\mathrm{g})$, seed index $(\mathrm{g})$ and seed cotton yield per plant. Seed cotton yield kentar per feddan (kentar (ken.) $=157.5 \mathrm{~kg}$ and feddan (fed.) $=4200 \mathrm{~m}^{2}$ ) was calculated from the two central rows of each plot after multiplying by the appropriate conversion factor. Lint cotton $\%$ (calculated from lint weight to seed cotton weight expressed as percentage).

\section{Fiber properties}

Fiber properties of Giza 92, Giza 94 and Giza 95 across the two growing seasons were measured as the following; fiber length ( $\mathrm{mm})$, uniformity ratio (\%) was determined by the digital fibrograph, fiber strength (g/tex) by using the Pressely tester at zero-gauge length and fiber fineness (micronair reading) measured by micronair apparatus, fiber elongation $(\%)$ and color attributes values i.e., Reflectance $(\mathrm{Rd} \%)$ and Yellowness $(+b \%)$. All fiber tests were carried out at the Laboratories of the Cotton Research Institute, Agricultural Research Center, Giza, Egypt, under controlled conditions of $70^{\circ} \mathrm{F} \pm 2$ temperature and $65 \% \pm 2$ of relative humidity.

\section{Statistical analysis}

The obtained data were subjected to statistical analysis of variance for each season, for 
all characters under study according to the procedure described by Snedecor and Cochron (1981). Significance of differences among variables were done according to Least Significant
Differences test (LSD) at 5\% level of probability. Finally, all statistical analyses were carried out using "MSTAT-C" computer software package (Freed et al., 1989). 
(JAAR) Volume: 26 (4)

Table 1. Some physical and chemical properties of the experiments soil during 2019 and 2020 cotton growing seasons.

\begin{tabular}{|c|c|c|c|c|c|c|}
\hline \multirow{3}{*}{ Soil characteristics } & \multicolumn{6}{|c|}{ Seasons } \\
\hline & \multicolumn{3}{|c|}{$\begin{array}{c}2019 \\
\text { Soil depth }(\mathrm{cm})\end{array}$} & \multicolumn{3}{|c|}{$\begin{array}{c}2020 \\
\text { Soil depth }(\mathrm{cm}) \\
\end{array}$} \\
\hline & 0-30 & $30-60$ & $60-90$ & $0-30$ & $30-60$ & $60-90$ \\
\hline \multicolumn{7}{|l|}{ Physical properties: } \\
\hline C. Sand\% & 4.15 & 5.25 & 6.25 & 4.72 & 5.58 & 6.05 \\
\hline F. Sand $\%$ & 36.50 & 33.52 & 37.50 & 35.54 & 34.15 & 38.41 \\
\hline Silt\% & 27.95 & 26.69 & 29.15 & 29.52 & 27.30 & 27.54 \\
\hline Clay\% & 31.42 & 34.55 & 27.25 & 30.25 & 33.05 & 28.15 \\
\hline Texture* & C. L. & C. L. & C. L. & C. L. & C. L. & C. L. \\
\hline Soil bulk density $\left(\mathrm{gcm}^{-3}\right)$ & 1.18 & 1.35 & 1.38 & 1.15 & 1.31 & 1.35 \\
\hline \multicolumn{7}{|l|}{ Chemical properties: } \\
\hline pH (paste extract) & 7.72 & 7.84 & 7.97 & 7.75 & 8.02 & 8.12 \\
\hline $\mathrm{EC}\left(\mathrm{dSm}^{-1}\right)$ & 1.95 & 2.27 & 2.48 & 1.96 & 2.48 & 2.87 \\
\hline Calcium carbonate $(\%)$ & 3.17 & 3.52 & 4.96 & 3.27 & 3.38 & 3.97 \\
\hline Organic matter $(\%)$ & 2.03 & 1.89 & 1.51 & 2.25 & 1.75 & 1.45 \\
\hline \multicolumn{7}{|c|}{ Plant available nutrients $\left(\mathrm{mg} \mathrm{kg}^{-1}\right)$} \\
\hline Nitrogen & 35.65 & 28.55 & 20.26 & 33.52 & 25.25 & 18.56 \\
\hline Phosphorus & 9.15 & 7.24 & 6.48 & 8.99 & 8.24 & 7.17 \\
\hline Potassium & 255 & 238 & 225 & 248 & 235 & 215 \\
\hline \multicolumn{7}{|l|}{ Total nutrients content } \\
\hline Nitrogen $\left(\mathrm{mg} \mathrm{kg}^{-1}\right)$ & 989 & 756 & 515 & 930 & 740 & 635 \\
\hline Phosphorus (mg kg-1) & 710 & 533 & 510 & 740 & 620 & 560 \\
\hline Potassium $(\%)$ & 2.33 & 2.24 & 2.12 & 2.35 & 2.25 & 2.10 \\
\hline
\end{tabular}

Potassium (\%)

$*$ C.L. = clay loam 
RESULTS AND DISCUSSIONS

Plant growth attributes

Plant height and position of $1^{\text {st }}$ sympodial node

It is quite evident from Table (2) that planting methods (direct seeding and transplantation) and cotton cultivars recorded significant differences at the $5 \%$ level of probability regarding plant height and the first sympodial node position in both seasons. However, plant height was $151.9 \mathrm{~cm}$ for transplanting and $137.5 \mathrm{~cm}$ for directed seeding method which recorded $10.46 \%$ increase; also, position of $1^{\text {st }}$ sympodial node was 6.55 for transplanting and 7.63 for directed seeding method which recorded $14.17 \%$ decrease as an average of both seasons. In this regard, Hemeid et al. (2018) and Emara et al. (2018 and 2021) found that the tallest plants were recorded in the transplanted plants than normal seeding. Cotton cultivars recorded a significant difference in plant height in the following order; Giza 92 (159.5) > Giza 95 (144.1) > Giza $94(130.5 \mathrm{~cm})$ as an average of both seasons. The interaction between planting methods and cotton cultivars for plant height and first sympodial node position were significant. In both seasons as an average, the $164.59 \mathrm{~cm}$ was recorded for Giza 92 under transplantation and the shortest one $(127.8 \mathrm{~cm})$ was recorded for Giza 94 under direct seeding method. However, the lowest position of $1^{\text {st }}$ sympodial node (6.33) was recorded for Giza 95 under transplantation and the highest one (7.94) was recorded for Giza 92 under direct seeding method.

\section{Seed cotton yield and its components Sympodial branches per plant} Data in both seasons (Table 2) indicate that, significant variation in open bolls per plant in the the main effect of planting methods, cotton cultivars following order; Giza 95 (20.99) > Giza 94 (17.25) and their interaction recorded a significant effect on > Giza 92 (14.36) as an average of both seasons. the number of sympodial branches per plant. The interaction between planting methods and Sympodial branches per plant in transplantation cotton cultivars for number of open bolls per plant (17.0) were more than those in direct seeding (16.11) showed significant effect in both seasons as an as an average, which recorded higher value (5.54\%) average, the highest number (21.06) was recorded for transplantation than direct seeding method. for Giza 95 under direct seeding and the lowest one These results are in the same line with those of (14.10) was recorded for Giza 92 under Sarvestani and Kordi (2001); Hemeid et al. (2018) transplantation method. The decrease of open bolls and Emara et al. (2018 and 2021) they found that may be due to the high-density leaves in plants transplanted cotton increased sympodia than direct during the boll opening stage, therefore we suggest seeding. Cotton cultivars varied significantly in the using leaves drop agent to remove leaves to number of sympodial branches per plant as increase penetration of sun light to plants which following order; Giza 95 (17.60) > Giza 92 (16.56) increase the number of open bolls.

$>$ Giza 94 (15.51) as an average in the both seasons.

The highest increase was recorded at Giza 95 $(13.46 \%)$, followed by Giza $92(6.77 \%)$ compared with Giza 94. The interaction between planting sympodial branches per plant showed significant effect, whereas, as an average for both seasons, the highest value (18.14) was recorded for Giza 95 under transplantation and the lowest one (15.55) was

\section{Total and open bolls per plant}

Total bolls per plant were significantly only by cotton cultivars, however methods treatments and their interaction (Table 2). As an averaged across two seasons Cotton per plant recorded increases in total bolls number Giza 94 (24.79) > Giza 92 (20.5). However, lanting methods led to significant differences in bolls per plant whereas direct seeding transplantation (16.89) as an average of both seasons, which was hiegher by $7.57 \%$ for direct bolls than transplantation method. Lower open due to BRT plants flowered and matured much ater and were heavily affected by boll weevils thon direct seeded cotton. This finding agrees with Ismail et al. (2000), however it disagrees with of Sarvestani and Kordi (2001); Hemeid et al. (2018) and Emara et al. (2018 and 2021) who transplanted cotton increased open bolls per plant than direct seeded. Cotton cultivars recorded d

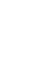

(1)

.

.


Table 2. Mean values of planting methods, cotton cultivars and their interaction for cotton plant height, position of $1^{\text {st }}$ sympodial node, sympodial branches per plant, total and open bolls per plant during 2019 and 2020 seasons.

\begin{tabular}{|c|c|c|c|c|c|c|c|c|c|c|c|}
\hline \multirow[t]{3}{*}{$\begin{array}{l}\text { Planting } \\
\text { methods }\end{array}$} & \multirow[t]{3}{*}{ Cultivars } & \multicolumn{2}{|c|}{$\begin{array}{l}\text { Plant height } \\
\quad(\mathrm{cm})\end{array}$} & \multicolumn{2}{|c|}{$\begin{array}{c}\text { Position of } \\
1^{\text {st }} \text { sympodial } \\
\text { node }\end{array}$} & \multicolumn{2}{|c|}{$\begin{array}{c}\text { Sympodial } \\
\text { branches plant }^{-1} \\
(\text { No) }\end{array}$} & \multicolumn{2}{|c|}{$\begin{array}{c}\text { Total } \\
\text { bolls plant }^{-1} \\
(\text { No }) \\
\end{array}$} & \multicolumn{2}{|c|}{$\begin{array}{c}\text { Open } \\
\text { bolls plant }^{-1} \\
(\mathrm{No}) \\
\end{array}$} \\
\hline & & \multicolumn{10}{|c|}{ Growing seasons } \\
\hline & & 2019 & 2020 & 2019 & 2020 & 2019 & 2020 & 2019 & 2020 & 2019 & 2020 \\
\hline Direct seeding & & $138.33 b$ & $136.67 b$ & $7.78 \mathrm{a}$ & $7.48 \mathrm{a}$ & $16.41 b$ & $15.81 \mathrm{~b}$ & 24.59 & 24.59 & $18.04 \mathrm{a}$ & $18.30 \mathrm{a}$ \\
\hline $\begin{array}{c}\text { Transplanting } \\
\text { F. test }\end{array}$ & & $\begin{array}{l}152.52 \mathrm{a} \\
\mathrm{Sig}\end{array}$ & $\begin{array}{l}\text { 151.23a } \\
\text { Sig }\end{array}$ & $\begin{array}{l}6.63 b \\
\text { Sig }\end{array}$ & $\begin{array}{l}6.47 b \\
\text { Sig }\end{array}$ & $\begin{array}{l}17.14 \mathrm{a} \\
\mathrm{Sig}\end{array}$ & $\begin{array}{l}16.87 \mathrm{a} \\
\text { Sig }\end{array}$ & $\begin{array}{l}25.64 \\
\text { NS }\end{array}$ & $\begin{array}{c}24.28 \\
\text { NS }\end{array}$ & $\begin{array}{l}17.17 \mathrm{~b} \\
\mathrm{Sig}\end{array}$ & $\begin{array}{c}16.62 b \\
\text { Sig }\end{array}$ \\
\hline \multirow{5}{*}{ LSD } & Giza 92 & $160.42 \mathrm{a}$ & $158.62 \mathrm{a}$ & $7.44 \mathrm{a}$ & $7.14 \mathrm{a}$ & $16.57 \mathrm{~b}$ & $16.55 \mathrm{~b}$ & $20.93 c$ & $20.08 c$ & $14.60 \mathrm{c}$ & $14.11 \mathrm{c}$ \\
\hline & Giza 94 & $134.39 \mathrm{c}$ & $126.53 c$ & $7.36 \mathrm{a}$ & $6.77 \mathrm{~b}$ & $16.28 b$ & $14.75 \mathrm{c}$ & $26.09 \mathrm{~b}$ & $23.50 \mathrm{~b}$ & $17.84 \mathrm{~b}$ & $16.66 \mathrm{~b}$ \\
\hline & Giza 95 & $141.48 b$ & $146.69 b$ & $6.81 \mathrm{~b}$ & $7.01 \mathrm{ab}$ & $17.47 \mathrm{a}$ & $17.73 \mathrm{a}$ & $28.35 \mathrm{a}$ & $29.73 a$ & $20.36 \mathrm{a}$ & $21.61 \mathrm{a}$ \\
\hline & & 7.02 & 7.90 & 0.41 & 0.26 & 0.84 & 0.94 & 1.49 & 1.67 & 0.71 & 1.67 \\
\hline & Giza 92 & $158.89 \mathrm{a}$ & $150.00 \mathrm{~b}$ & $8.00 \mathrm{a}$ & $7.89 \mathrm{a}$ & $16.11 b$ & $15.33 b$ & $20.79 a$ & $19.63 \mathrm{a}$ & $15.00 \mathrm{~d}$ & $14.22 \mathrm{c}$ \\
\hline \multirow[t]{3}{*}{ Direct seeding } & Giza 94 & $129.44 b c$ & $126.11 \mathrm{c}$ & $7.67 \mathrm{a}$ & $7.22 b$ & $16.22 b$ & $14.89 \mathrm{~b}$ & $25.65 a$ & $25.23 \mathrm{a}$ & $18.89 \mathrm{~b}$ & $18.78 b$ \\
\hline & Giza 95 & $126.67 \mathrm{c}$ & $133.89 \mathrm{c}$ & $7.67 \mathrm{a}$ & $7.33 b$ & $16.89 \mathrm{ab}$ & $17.22 \mathrm{a}$ & $27.34 \mathrm{a}$ & $28.92 \mathrm{a}$ & $20.22 \mathrm{a}$ & $21.89 \mathrm{a}$ \\
\hline & Giza 92 & $161.94 a$ & $167.24 \mathrm{a}$ & $6.88 b$ & $6.40 \mathrm{~cd}$ & $17.03 \mathrm{ab}$ & $17.76 \mathrm{a}$ & $21.06 \mathrm{a}$ & $20.52 \mathrm{a}$ & $14.20 \mathrm{~d}$ & $14.00 \mathrm{c}$ \\
\hline \multirow[t]{2}{*}{ Transplanting } & Giza 94 & $139.33 b$ & $126.96 \mathrm{c}$ & $7.05 b$ & $6.32 \mathrm{~d}$ & $16.33 b$ & $14.61 \mathrm{~b}$ & $26.52 \mathrm{a}$ & $21.77 \mathrm{a}$ & $16.80 \mathrm{c}$ & $14.53 \mathrm{c}$ \\
\hline & Giza 95 & $156.29 \mathrm{a}$ & $159.50 \mathrm{ab}$ & $5.96 \mathrm{c}$ & $6.69 c$ & $18.05 \mathrm{a}$ & $18.24 \mathrm{a}$ & $29.36 a$ & $30.55 a$ & $20.50 \mathrm{a}$ & $21.33 \mathrm{a}$ \\
\hline LSD & & 9.90 & 11.26 & 0.57 & 0.36 & 1.19 & 1.33 & NS & NS & 1.01 & 2.37 \\
\hline
\end{tabular}

Means sharing different letters differ significantly from each other at $\mathrm{p}(\leq 0.05)$. 


\section{Boll weight}

In both seasons the analysis of variance for boll weight $(\mathrm{g})$ showed a significant effect of planting methods, cotton cultivars and the interaction between them (Table 3). Whereas, boll weight in direct seeding $(2.07 \mathrm{~g})$ was more than that of transplantation $(2.01 \mathrm{~g})$ as an average of the two seasons, which recorded higher percentage value $(2.99 \%)$ for direct seeding than transplantation method. These results might be due to that higher-density leaves in transplanted cotton plants leads to the lower efficient utilization of solar radiation resulting in decreasing the photosynthetic rate therefore decreasing accumulation of dry matter in leaves, so less photosynthates translocation from source (leaves) to sink (boll) and thus boll weight decreases. High plant population has been found to give taller plants and reduced boll weight (Wali and Koraddi, 1989). Cotton cultivars recorded increase in boll weight in the following order; Giza 95 (2.32) > Giza 94 (1.92) > Giza 92 (1.89 g). The interaction between studies factors (Table 3 ) showed a significant effect on boll weight in both seasons. The highest boll weight value was $2.39 \mathrm{~g}$ for Giza 95 under direct seeding planting method however the lowest one was $1.88 \mathrm{~g}$ for Giza 92 under transplantation method as an average of both seasons.

\section{Seed index}

Results cleared that, seed index (g) was significantly influenced by planting methods, cotton cultivars and the interaction between them (Table 3). Whereas, seed index in direct seeding $(9.59 \mathrm{~g})$ was higher than that in transplantation $(8.97 \mathrm{~g})$ as an average of both seasons, which recorded higher percentage increase $(6.91 \%)$ for direct seeding than transplantation method. These results might be due to the decrease in mobilization of photosynthates and directly influenced boll weight that coincide with decreased seed index. Cotton cultivars recorded increases in seed index in the following order; Giza $94(9.99$ g) > Giza 95 (9.03 g) > Giza 92 (8.82 $\mathrm{g})$. The interaction between study factors (Table 3 ) cleared a significant effect on seed index in both seasons. The highest seed index was (10.68 g) for Giza 94 under direct seeding planting method however the lowest one was (8.8 g) for Giza 92 under transplantation method as an average of both seasons.

\section{Lint percentage}

Lint percentage was influenced Insignificantly and significantly by planting methods and cotton cultivars, respectively in both seasons (Table 3). Cotton cultivars recorded increases in lint percentage in the following order; Giza $95(38.06 \%)>$ Giza 94 (36.98\%) > Giza 92
$(34.26 \%)$. The interaction between study factors (Table 3) was significant for lint percentage in both seasons. The highest lint percentage was $38.90 \%$ for Giza 95 under direct seeding planting method and the lowest value was $34.03 \%$ for Giza 92 under direct seeding planting method as an average of both seasons.

\section{Seed cotton yield per plant}

Seed cotton yield per plant $(\mathrm{g})$ was significantly influenced by planting method, cotton cultivars and their interaction in both seasons (Table 3). Whereas, direct seeding produced higher seed cotton per plant $(35.5 \mathrm{~g})$ than transplantation $(33.37 \mathrm{~g})$ as an average of two seasons, which was higher by $6.38 \%$ than transplantation method. These findings agree with those of Rehab (1963); Abdel-Ghaffar et al. (1976) and Radwan (1988) they reported that transplanting cotton seedlings with bare root yielded less than direct seeding due to the damages usually happens to the root system during transplanting process. Regarding cotton cultivars seed cotton yield per plant varied in the following order; Giza 95 (39.44) > Giza 94 (33.76) $>$ Giza 92 (30.11 g). The interaction between study factors (Table 3) shwoed a significant effect on seed cotton yield per plant in both seasons. The highest seed cotton yield per plant was (39.66 g) for Giza 95 under direct seeding planting method and the lowest value was (29.42 g) for Giza 92 under transplantation method as an average of both seasons.

\section{Seed cotton yield per feddan}

Data in both seasons showed that, seed cotton yield (ken./fed.) was significantly influenced by planting methods, cotton cultivars and their interaction in both seasons (Table 3). Whereas, seed cotton yield per feddan in direct seeding (8.54) was more than that in transplantation (7.96 ken. /fed.) which was higher by $7.29 \%$ than transplantation method. The same trend was reported by Hamed (1995); Dwedar (1998) and Ismail et al. (2000) They concluded that seed-cotton yield of direct seeded cotton was higher than transplanted cotton. Cotton cultivars recorded increases in seed cotton yield per feddan in the following order; Giza 95 (9.32) > Giza 94 (8.31) > Giza 92 (7.12 ken. /fed.). The interaction between study factors (Table 3) cleared a significant effect on seed cotton yield per feddan in both seasons. The highest seed cotton yield was (9.8 ken. /fed) for Giza 95 under direct seeding planting method however the lowest value was (7.08 ken. /fed.) for Giza 92 under transplantation method as an average of both seasons. Results of this study showed that seed cotton yield, whether per plant or per feddan, was higher in the direct seeding method than transplanting method, this might be due to the increase in open bolls per plant, 
(JAAR) Volume: 26 (4)

boll weight and seed index as a result of direct seeding method, which contradicts many previous studies and could be due to the fact that we did not use leaves drop agent 
(JAAR) Volume: 26 (4)

Table 3. Mean values of planting methods, cotton cultivars and their interaction for cotton boll weight, seed index, lint cotton \%, seed cotton yield per plant and per feddan during 2019 and 2020 seasons.

\begin{tabular}{|c|c|c|c|c|c|c|c|c|c|c|c|}
\hline \multirow[t]{2}{*}{ Planting methods } & \multirow[t]{2}{*}{ Cultivars } & \multicolumn{2}{|c|}{$\begin{array}{l}\text { Boll weight } \\
\quad(\mathrm{g})\end{array}$} & \multicolumn{2}{|c|}{$\begin{array}{l}\text { Seed index } \\
\quad(\mathrm{g})\end{array}$} & \multicolumn{2}{|c|}{$\begin{array}{l}\text { Lint cotton } \\
\quad(\%)\end{array}$} & \multicolumn{2}{|c|}{$\begin{array}{l}\text { Seed cotton } \\
\text { yield plant }{ }^{-1} \\
\text { (g) }\end{array}$} & \multicolumn{2}{|c|}{$\begin{array}{l}\text { Seed cotton yield } \\
\text { fed }^{-1} \text { (Ken.) }\end{array}$} \\
\hline & & 2019 & 2020 & 2019 & 2020 & 2019 & 2020 & 2019 & 2020 & 2019 & 2020 \\
\hline Direct seeding & & $2.08 \mathrm{a}$ & $2.06 a$ & $9.58 \mathrm{a}$ & $9.60 \mathrm{a}$ & 36.56 & 36.48 & $35.53 a$ & $35.46 \mathrm{a}$ & $8.51 \mathrm{a}$ & $8.57 \mathrm{a}$ \\
\hline Transplanting & & $2.01 \mathrm{~b}$ & $2.00 \mathrm{~b}$ & $8.95 b$ & $8.98 b$ & 36.35 & 36.34 & $33.58 \mathrm{~b}$ & $33.16 \mathrm{~b}$ & $8.01 b$ & $7.92 b$ \\
\hline F. test & & Sig & Sig & Sig & Sig & NS & NS & Sig & Sig & Sig & Sig \\
\hline \multirow[b]{4}{*}{ LSD } & Giza 92 & $1.90 \mathrm{~b}$ & $1.86 \mathrm{~b}$ & $8.77 b$ & $8.86 \mathrm{~b}$ & $34.14 \mathrm{c}$ & $34.39 \mathrm{c}$ & $30.38 \mathrm{c}$ & $29.84 \mathrm{c}$ & $7.22 \mathrm{c}$ & $7.03 \mathrm{c}$ \\
\hline & Giza 94 & $1.95 b$ & $1.88 b$ & $10.08 \mathrm{a}$ & $9.91 \mathrm{a}$ & $37.19 b$ & $36.77 b$ & $34.25 b$ & $33.26 \mathrm{~b}$ & $8.27 b$ & $8.34 b$ \\
\hline & Giza 95 & $2.29 a$ & $2.34 \mathrm{a}$ & $8.94 b$ & $9.11 b$ & $38.04 \mathrm{a}$ & $38.08 \mathrm{a}$ & $39.04 a$ & $39.84 a$ & $9.30 \mathrm{a}$ & $9.35 \mathrm{a}$ \\
\hline & & 0.06 & 0.04 & 0.41 & 0.30 & 0.78 & 1.23 & 1.02 & 1.64 & 0.34 & 0.36 \\
\hline \multirow{4}{*}{ Direct seeding } & Giza 92 & $1.90 \mathrm{c}$ & $1.86 \mathrm{c}$ & $8.97 b c$ & $8.70 \mathrm{~d}$ & $33.88 \mathrm{c}$ & $34.18 \mathrm{~d}$ & $31.25 \mathrm{c}$ & $30.36 c$ & $7.25 \mathrm{~d}$ & $7.07 \mathrm{~d}$ \\
\hline & Giza 94 & $1.96 \mathrm{c}$ & $1.91 \mathrm{c}$ & $10.73 a$ & $10.63 a$ & $37.07 \mathrm{~b}$ & $36.20 b c$ & $36.11 \mathrm{~b}$ & $35.95 b$ & $8.50 \mathrm{bc}$ & $8.82 b$ \\
\hline & Giza 95 & $2.38 \mathrm{a}$ & $2.39 a$ & $9.03 b c$ & $9.48 b$ & $38.74 a$ & $39.06 a$ & $39.25 a$ & $40.07 \mathrm{a}$ & $9.78 \mathrm{a}$ & $9.81 \mathrm{a}$ \\
\hline & Giza 92 & $1.89 \mathrm{c}$ & $1.87 \mathrm{c}$ & $8.57 \mathrm{c}$ & $9.02 \mathrm{~cd}$ & $34.40 \mathrm{c}$ & $34.60 \mathrm{~cd}$ & $29.52 d$ & $29.31 \mathrm{c}$ & $7.18 \mathrm{~d}$ & $6.98 d$ \\
\hline \multirow[t]{2}{*}{ Transplanting } & Giza 94 & $1.94 \mathrm{c}$ & $1.86 \mathrm{c}$ & $9.43 b$ & $9.18 b c$ & $37.31 \mathrm{~b}$ & $37.33 \mathrm{ab}$ & $32.39 \mathrm{c}$ & $30.58 \mathrm{c}$ & $8.03 c$ & $7.87 \mathrm{c}$ \\
\hline & Giza 95 & $2.21 b$ & $2.29 b$ & $8.86 b c$ & $8.74 d$ & $37.34 b$ & $37.09 b$ & $38.82 \mathrm{a}$ & $39.60 \mathrm{a}$ & $8.81 b$ & $8.90 \mathrm{~b}$ \\
\hline LSD & & 0.08 & 0.06 & 0.58 & 0.42 & 1.11 & 1.74 & 1.45 & 2.32 & 0.48 & 0.52 \\
\hline
\end{tabular}




\section{Cotton fiber properties}

Cotton fiber length, uniformity index fiber bundle strength, micronaire reading, fiber elongation, color as reflectance $(\mathrm{Rd} \%)$ and yellowness $(+b)$ has been defined as the quality of cotton fibers needed for textile production (Watts et al., 2014). The effect of planting methods and cotton cultivars on these traits will be discussed as follows:

\section{Fiber length}

In both seasons fiber length $(\mathrm{mm})$ was significantly influenced by cotton cultivars, while insignificantly effect by planting methods and the interaction between cotton cultivars and planting methods (Table 4). Cotton cultivars recorded different values of fiber length in the following order; Giza 92 (32.9) > Giza 94 (31.3) > Giza 95 (30.28 mm). Giza 92 is an extra-long staple cultivar while Giza 94 and Giza 95 are long staple cultivars according to Cotton Incorporated (2013) classification.

\section{Length uniformity index $(\%)$}

Fiber uniformity is important because it reduces waste and yarn breakage (Glade, 1981). In both seasons, length uniformity index was significantly influenced by planting methods, cotton cultivars and interactions between them (Table 4). Whereas, length uniformity index in direct seeding $(85.84 \%)$ was higher than that in transplantation $(82.83 \%)$ as an average of two seasons, which was higher by $3.63 \%$ than transplantation method. Cotton cultivars recorded different values in length uniformity index in the following order; Giza 95 (84.7) at par with Giza 94 (84.6) > Giza $92(83.7 \%)$. The interaction between study factors (Table 4) showed a significant effect on length uniformity index in both seasons. The highest length uniformity index value was $(86.1 \%)$ for Giza 94 under direct seeding planting method however the lowest one was $(81.8 \%)$ for Giza 92 under transplantation method as an average of both seasons. Obtained values for uniformity index are considered high according to (Cotton Incorporated, 2013) which mentioned values 83 to $85 \%$ are high fiber uniformity which is important in cotton manufacturing processing because it reduces waste and yarn breakage (Glade, 1981).

\section{Fiber bundle strength}

Yarn spinning ability has a good indication for fiber bundle strength, cotton varieties which produce weak fiber (low strength), are difficult to be handled in manufacturing process. Fiber bundle strength is the force required to break a standard bundle of cotton fibers. Fiber bundle Strength measurements are reported in $\mathrm{g}$ tex ${ }^{-1}$ with a tex unit being the weight $(\mathrm{g})$ of $1000 \mathrm{~m}$ of cotton fiber (USDA-AMS, 1980). In both seasons, the analysis of variance showed a significant influence on fiber bundle strength by planting method, cotton cultivars and interactions between them (Table 4). Regarding planting methods fiber bundle strength in direct seeding (40.96 g/tex) was higher than that in transplantation (38.05 g/tex) as an average of two seasons, which was $7.65 \%$ higher than transplantation method. Cotton cultivars showed fiber bundle strength values $40.28 \mathrm{~g} /$ tex (Giza 94) > $39.27 \mathrm{~g} /$ tex (Giza 95) > $38.95 \mathrm{~g} /$ tex (Giza 92). This trend agrees with Subhan et al. (2001) and Bednarz et al. (2005) they mentioned that, cotton fiber quality is mainly influenced by genotype of the cultivars but agronomic practices and environmental conditions are the secondary factors influencing fiber quality. The interaction between study factors represented a high fiber bundle strength value (41.57 g/tex) for Giza 94 in direct seeding method and a low one $\left(36.84 \mathrm{~g} \mathrm{tex}^{-1}\right)$ for Giza 92 in transplanting method as an average of both seasons. All fiber bundle strength measurements fell into the base or strong range and therefore would not have affected cotton value according to Watts et al. (2014).

\section{Fiber fineness (micronaire reading)}

In both seasons, micronaire reading was significantly influenced by planting methods, cotton cultivars and interactions between them (Table 4). Whereas, micronaire reading in transplantation (3.96) was more than that in direct seeding (3.59) as an average of two seasons, which recorded $10.3 \%$ higher than direct seeding method. Cotton cultivars showed micronaire reading values $4.21($ Giza 95) > $3.80($ Giza 94) > 3.29 (Giza 92). The interaction between study factors represented a high value (4.30) for Giza 95 in transplanting method and a low value (2.87) for Giza 92 in direct seeding methods as an average of both seasons. Therefore, the most fineness cultivar is Giza 92. Similar differences in micronaire values due to cultivar have also been reported by Faircloth et al. (2004).

\section{Fiber elongation (\%)}

The degree of fiber elongation before rupture plays an important role in almost all textile manufacturing processes as mentioned by Benzina et al. (2007) and Mathangadeera et al. (2020). In both seasons, fiber elongation (\%) was insignificantly influenced by planting methods while, significant effect was found by cotton cultivars and interactions between them (Table 5). Cotton cultivars recorded different values in fiber elongation in the following order; Giza 94 (7.37) > Giza 95 (7.31) > Giza 92 (6.68\%). The interaction between study factors (Table 5) cleared a significant effect on fiber elongation in both seasons. The highest value was $(7.53 \%)$ for Giza 
(JAAR) Volume: 26 (4)

94 under transplantation method however the transplantation method as an average of both lowest one was $(6.13 \%)$ for Giza 92 under seasons. 
(JAAR) Volume: 26 (4)

Table 4. Mean values of planting methods, cotton cultivars and their interaction for cotton fiber length, length uniformity index, fiber bundle strength and fiber fineness during 2019 and 2020 seasons.

\begin{tabular}{|c|c|c|c|c|c|c|c|c|c|}
\hline \multirow[t]{2}{*}{ Planting methods } & \multirow[t]{2}{*}{ Cultivars } & \multicolumn{2}{|c|}{$\begin{array}{l}\text { Fiber length } \\
\qquad(\mathrm{mm})\end{array}$} & \multicolumn{2}{|c|}{$\begin{array}{l}\text { Length uniformity } \\
\text { index }(\%)\end{array}$} & \multicolumn{2}{|c|}{$\begin{array}{l}\text { Fiber bundle } \\
\text { strength } \\
\text { (g/tex) }\end{array}$} & \multicolumn{2}{|c|}{$\begin{array}{c}\text { Fiber fineness } \\
\text { (micronaire reading) }\end{array}$} \\
\hline & & 2019 & 2020 & 2019 & 2020 & 2019 & 2020 & 2019 & 2020 \\
\hline Direct seeding & & $31.91 \mathrm{a}$ & $31.80 \mathrm{a}$ & $86.01 \mathrm{a}$ & $85.67 \mathrm{a}$ & $41.18 \mathrm{a}$ & $40.73 a$ & $3.49 b$ & $3.68 b$ \\
\hline Transplanting & & $31.08 \mathrm{a}$ & $31.18 \mathrm{a}$ & $82.73 b$ & $82.93 b$ & $38.08 \mathrm{~b}$ & $38.02 b$ & $3.93 \mathrm{a}$ & $3.99 \mathrm{a}$ \\
\hline F. test & & $\mathrm{NS}$ & NS & Sig & Sig & Sig & Sig & Sig & Sig \\
\hline \multirow[b]{4}{*}{ LSD } & Giza 92 & $32.82 \mathrm{a}$ & $32.98 \mathrm{a}$ & $83.67 b$ & $83.75 b$ & $39.15 b$ & $38.78 b$ & $3.32 \mathrm{c}$ & $3.27 \mathrm{c}$ \\
\hline & Giza 94 & $31.32 b$ & $31.28 b$ & $84.58 \mathrm{a}$ & $84.55 \mathrm{a}$ & $40.07 \mathrm{a}$ & $40.48 \mathrm{a}$ & $3.78 b$ & $3.83 b$ \\
\hline & Giza 95 & $30.35 c$ & $30.20 \mathrm{c}$ & $84.87 \mathrm{a}$ & $84.60 \mathrm{a}$ & $39.67 \mathrm{ab}$ & $38.87 b$ & $4.03 \mathrm{a}$ & $4.40 \mathrm{a}$ \\
\hline & & 0.91 & 1.16 & 0.79 & 0.72 & 0.61 & 1.05 & 0.24 & 0.10 \\
\hline \multirow{4}{*}{ Direct seeding } & Giza 92 & $33.07 \mathrm{a}$ & $33.17 \mathrm{a}$ & $85.57 \mathrm{a}$ & $85.67 \mathrm{a}$ & $41.30 \mathrm{a}$ & $40.90 \mathrm{a}$ & $2.90 \mathrm{c}$ & $2.83 \mathrm{~d}$ \\
\hline & Giza 94 & $31.87 \mathrm{a}$ & $31.90 \mathrm{a}$ & $86.03 a$ & $86.13 a$ & $41.03 \mathrm{a}$ & $42.10 \mathrm{a}$ & $3.70 \mathrm{~b}$ & $3.80 \mathrm{bc}$ \\
\hline & Giza 95 & $30.80 \mathrm{a}$ & $30.33 a$ & $86.43 \mathrm{a}$ & $85.20 \mathrm{a}$ & $41.20 \mathrm{a}$ & $39.20 b$ & $3.87 \mathrm{ab}$ & $4.40 \mathrm{a}$ \\
\hline & Giza 92 & $32.57 \mathrm{a}$ & $32.80 \mathrm{a}$ & $81.77 \mathrm{c}$ & $81.83 \mathrm{~d}$ & $37.00 \mathrm{~d}$ & $36.67 \mathrm{c}$ & $3.73 b$ & $3.70 \mathrm{c}$ \\
\hline \multirow[t]{2}{*}{ Transplanting } & Giza 94 & $30.77 \mathrm{a}$ & $30.67 a$ & $83.13 b$ & $82.97 \mathrm{c}$ & $39.10 b$ & $38.87 \mathrm{~b}$ & $3.87 \mathrm{ab}$ & $3.87 \mathrm{~b}$ \\
\hline & Giza 95 & $29.90 \mathrm{a}$ & $30.07 a$ & $83.30 \mathrm{~b}$ & $84.00 \mathrm{~b}$ & $38.13 c$ & $38.53 b$ & $4.20 \mathrm{a}$ & $4.40 \mathrm{a}$ \\
\hline LSD & & NS & $\mathrm{NS}$ & 1.13 & 1.02 & 0.87 & 1.48 & 0.34 & 0.13 \\
\hline
\end{tabular}

Means sharing different letters differ significantly from each other at $\mathrm{p}(\leq 0.05)$. 
(JAAR) Volume: 26 (4)

\section{Color attributes}

Color is quantified from two parameters, degree of reflectance $(\operatorname{Rd} \%)$ which shows the brightness and yellowness degree $(+b)$ depicts the degree of cotton pigmentation based on colorimeter readings. In both seasons, brightness $(\mathrm{Rd} \%)$ and yellowness $(+\mathrm{b})$ were significantly influenced by planting methods, cotton cultivars and interactions between them (Table 5). Whereas, planting methods showed a significant difference in brightness $(\mathrm{Rd} \%)(68.09 \%)$ and yellowness $(+\mathrm{b})$ (9.75) in direct seeding comparing with brightness $(\operatorname{Rd} \%)(63.56 \%)$ and yellowness $(+b)(11.79)$ in transplantation as an average of two seasons. Cotton cultivars recorded different values in brightness (Rd\%); Giza 94 (69.04) > Giza 92 $(64.40)>$ Giza $95(64.04 \%)$ while for, yellowness (+b); Giza 95 (11.88) > Giza 92 (10.42) > Giza 94 $(9.99 \%)$. The interaction between study factors (Table 5) cleared a significant effect in both seasons. The highest brightness (Rd\%) was (72.33 $\%)$ for Giza 94 under direct seeding methods however, the lowest one was (62.35\%) for Giza 95 under transplantation method as an average of two seasons. On the other hand, yellowness $(+b)$ recorded the highest value (12.58) for Giza 95 under transplanting method and the lowest one (8.62) for Giza 92 under direct seeding method as an average of two seasons. 
(JAAR) Volume: 26 (4)

Table 5. Mean values of planting methods and cotton cultivars and their interaction for cotton fiber elongation, reflectance degree (Rd\%) and yellowness during 2019 and 2020 seasons.

\begin{tabular}{|c|c|c|c|c|c|c|c|}
\hline \multirow[t]{2}{*}{ Planting methods } & \multirow[t]{2}{*}{ Cultivars } & \multicolumn{2}{|c|}{$\begin{array}{c}\text { Fiber elongation } \\
(\%)\end{array}$} & \multicolumn{2}{|c|}{$\begin{array}{c}\text { Reflectance degree } \\
(\mathrm{Rd} \%)\end{array}$} & \multicolumn{2}{|c|}{$\begin{array}{l}\text { Yellowness } \\
(+b)\end{array}$} \\
\hline & & 2019 & 2020 & 2019 & 2020 & 2019 & 2020 \\
\hline Direct seeding & & $7.12 \mathrm{a}$ & $7.28 \mathrm{a}$ & $68.28 \mathrm{a}$ & $67.91 \mathrm{a}$ & $9.71 b$ & $9.79 b$ \\
\hline Transplanting & & $7.07 \mathrm{a}$ & $7.02 \mathrm{a}$ & $63.59 b$ & $63.54 b$ & $11.90 \mathrm{a}$ & $11.68 \mathrm{a}$ \\
\hline F. test & & $\mathrm{NS}$ & NS & Sig & Sig & Sig & Sig \\
\hline \multirow[b]{4}{*}{ LSD } & Giza 92 & $6.50 \mathrm{~b}$ & $6.87 b$ & $64.53 b$ & $64.28 b$ & $10.43 b$ & $10.38 b$ \\
\hline & Giza 94 & $7.42 \mathrm{a}$ & $7.33 \mathrm{a}$ & $69.62 \mathrm{a}$ & $68.47 \mathrm{a}$ & $9.90 \mathrm{c}$ & $10.10 \mathrm{~b}$ \\
\hline & Giza 95 & $7.37 \mathrm{a}$ & $7.25 \mathrm{a}$ & $63.65 b$ & $64.43 b$ & $12.08 \mathrm{a}$ & $11.72 \mathrm{a}$ \\
\hline & & 0.41 & 0.33 & 1.19 & 1.44 & 0.53 & 0.40 \\
\hline \multirow{4}{*}{ Direct seeding } & Giza 92 & $6.93 b$ & $7.53 \mathrm{a}$ & $66.40 \mathrm{~b}$ & $66.03 b$ & $8.67 \mathrm{e}$ & $8.57 \mathrm{e}$ \\
\hline & Giza 94 & $7.23 \mathrm{ab}$ & $7.20 \mathrm{a}$ & $72.90 \mathrm{a}$ & $71.77 \mathrm{a}$ & $9.47 d$ & $9.37 d$ \\
\hline & Giza 95 & $7.20 \mathrm{ab}$ & $7.10 \mathrm{a}$ & $65.53 b$ & $65.93 b$ & $10.99 \mathrm{c}$ & $11.43 b$ \\
\hline & Giza 92 & $6.07 \mathrm{c}$ & $6.20 \mathrm{~b}$ & $62.67 \mathrm{c}$ & $62.53 c$ & $12.20 \mathrm{~b}$ & $12.20 \mathrm{a}$ \\
\hline \multirow[t]{2}{*}{ Transplanting } & Giza 94 & $7.60 \mathrm{a}$ & $7.47 \mathrm{a}$ & $66.33 b$ & $65.17 \mathrm{~b}$ & $10.33 c$ & $10.83 c$ \\
\hline & Giza 95 & $7.53 a$ & $7.40 \mathrm{a}$ & $61.77 \mathrm{c}$ & $62.93 c$ & $13.17 \mathrm{a}$ & $12.00 \mathrm{a}$ \\
\hline LSD & & 0.57 & 0.51 & 1.60 & 2.04 & 0.75 & 0.56 \\
\hline
\end{tabular}

Means sharing different letters differ significantly from each other at $\mathrm{p}(\leq 0.05)$. 


\section{CONCLUSION AND RECOMMENDATIONS}

The overall goal of this study was to evaluate the effect of transplantation method on growth, yield and fiber quality of some Egyptian cotton cultivars. From the foregoing discussion, it may be concluded that the advantage of using transplanting of seedling i.e., reduced field duration, maintenance of plant population, sowing at optimum time, beneficial over sowing seeds under delayed crop raising situations, and also suitable for the farm with undesirable quality of irrigation water for germination. However, cotton is not highly amenable for transplanting due to its tap root system. Therefore, we recommended to conduct future studies about suitable nursery media for cotton seedling without disturbing the tap root and suitable agronomic practice.

\section{ACKNOWLEDGMENTS}

The author would like to thank the Scientific Research Department, Cairo University, Egypt for financial support during the field work.

\section{REFERENCES}

Abdel-Ghaffar, M. A., A. M. El-Shinnawy, S. I. Mesiha and H. M. Abou Zeid.1976. Studies on transplanting cotton seedlings. Agric. Res. Rev., 54: 51-55.

Ahmad, S., I. Muhammad, M. Taj, M. Abid, A. Shakeel and H. Mirza. 2018. Cotton productivity enhanced through transplanting and early sowing. Acta Scientiarum Biological Sci., 40: 1-7.

Akbar, H. M., M. Akram, M. W. Hassan, M. Hussain, M. Rafay and I. Ahmad. 2015. Growth, yield and water use efficiency of cotton (Gossypium hirsutum L.) sown under different planting techniques. Custos e Agronegocio, 11(1), pp.143-160.

Bakheit, E. S. 1965. Growing cotton by transplanting. M.Sc. Thesis, Faculty of Agric. Assiut Univ.

Bednarz, C. W., W. D. Shurley, W. S. Anthony and R. L. Nichols. 2005. Yield, quality, and profitability of cotton produced at varying plant densities. Agron. J. 97, 235-240.

Benzina, H., E. Hequet, N. Abidi, J. Gannaway, J. Y. Drean, O. Harzallah. 2007. Using fiber elongation to improve genetic screening in cotton breeding programs. Text. Res. J. 77, 770-778.

Choi, B. H., B. M. Kac and K. Y. Chung. 1992. Optimum transplanting date, fertilizer application rate and planting density for upland cotton. Korean Journal of Crop Sci., 37: 217-223.

Cotton Incorporated. 2013. U.S. cotton fiber chart. Cotton Inc. www.cottoninc.com /Cotton Fiber Chart/?Pg=5.
Dong, H., W. Li, W. Tang, Z. Li, and D. Zhang. 2007. Enhanced plant growth, development and fiber yield of $\mathrm{Bt}$ transgenic cotton by an integration of plastic mulching and seedling transplanting. Industrial Crops and Products, 26(3): 298-306.

Dwedar, M. D. H. 1998. The effect of transplanting and some cultural practices on cotton productivity and fiber quality in Fayoum region. M.Sc. Thesis, Faculty of Agric. El Fayoum, Cairo Univ. Egypt.

Emara, M. A. A., S. A. Hamoda, and F. Maha, M. A. Hamada. 2018. Effect of potassium silicate and NPK fertilization levels on cotton growth and productivity under different sowing dates. Egypt. J. Agron. The $15^{\text {th }}$ Int. Conf. Crop Sci., pp. 115-123.

Emara, M.A. and S.O. El-Sayed. 2021. Effect of transplanting cotton on growth, earliness, productivity and fiber quality as compared with early and late direct seeding under spraying with pix. Journal of Plant Production, 12(4), pp.385-397.

Faircloth, J. C., K. L. Edmisten, R. Wells, and A. M. Stewart. 2004. The influence of defoliation timings on yields and quality of two cotton cultivars. Crop Sci., 44:165172.

Freed, R.S.P., S. Eisensmith, D. Goetz, V. Reicosky, W. Smail, P. Wolber.1989. User's Guide to MSTAT-C: A Software Program for the Design, Management and Analysis of Agronomic Research Experiments Michigan State University, East Lansing, ML, USA.

Glade, E. H. 1981. Cotton quality evaluation: Testing methods and use (Vol. 668). US Department of Agriculture, Economic Research Service.

Hamed, F. S. 1995. Effect of transplanting on growth and yield of Egyptian cotton. M.Sc. Thesis, Faculty of Agric. Assiut Univ. Egypt

Hemeid, M. M., M. M. Zeid and A. I. Nawar. 2018. Utilization of thinned cotton plants through bare-root transplanting coupled with foliar application of nutrients. Alex. Sci. Excha. J., 39 (January-March), pp.4855.

Ismail, F. M., M. R. A. Abd El-Malak and M. D. Hassan. 2000. Effect of transplanting and some cultural practices on earliness, productivity and some technological fiber properties of Egyptian cotton. Mansoura J. Agric. Sci., 25(12): 7345-7356.

Jackson, M. L. 1973. Soil chemical analysis prentice Hell of India Private Limited, New Delhi. 
Jahromi, A.M. and M. Mahboubi. 2012. Evaluate the cotton transplantation and its impact on yield performance components in saline lands. Advances in Environ. Biol., 6,13041306.

Kamel, A. S., K. E. El-Habbak, M. A. El-Masry, M. M. ElMihi and M. A. Abou-Kresha. 1991. New agro techniques in transplanting cotton in Egypt. Ann. Agr. Sci, Moshtohor, 29(2): 681-687.

Karve, A. D. 2003. High yield of rainfed cotton through transplanting. Curr. Sci., 85 (2):122-123.

Keeney, D. R. and D. W. Nelson. 1982. Methods of soil analysis. Agron. 9, Part 2: Chemical and microbiological properties, 2nd ed., Am. Soc. Agron., Madison, WI, USA.

Leskovar, D. I. and Y. A. Othman. 2021. Direct seeding and transplanting influence root gynamics, morpho-physiology, yield, and head quality of globe artichoke. plants, 10(5), 899-911.

Mathangadeera, R.W., E. F. Hequet, B. Kelly, J. K. Dever, and C. M. Kelly. 2020. Importance of cotton fiber elongation in fiber processing. Industrial Crops and Products, 147, p.112-217.

Radwan, F. E. 1988. Evaluation of some methods of cotton planting in relation to their effect on yield and quality. M. Sc. Thesis, Fac. of Agric. At Moshtohor, Zagazig Univ., Egypt.

Rajpoot, S., D. S. Rana, and A. K. Choudhary. 2016. Influence of diverse crop management practices on weed suppression, crop and water productivity and nutrient dynamics in Bt-cotton (Gossypium hirsutum)-based intercropping systems in a semi-arid Indo-Gangetic plains. Indian J. of Agri. Sci., 86(12), pp.1637.

Rehab, F. I. 1963. Physiological studies on cotton plant. Ph. D. Thesis, Fac. of Agric., Alex. Univ., Egypt.

Sarvestani Tahmasebi, Z. and M. Kordi. 2001. Evaluation of cotton Transplanting in saline Soils. Proceedings of the 10th Australian Agronomy Conference, pp 3.

Seif-El-Nasr, F. M., Z. M. Attia, H. E. Khalil, S. A. A. Shams and A. S. Kamel. 1996. Growing long duration winter crop in cotton rotation. Annals of Agric. Sci. Moshtohor, 34: 501-512.

Snedecor, G. W. and W. G. Cochron. 1981. Statistical Methods 7th ed. Iowa State Univ., Press, Ames, Iowa.

Subhan, M., H. U. Khan and R. O. Ahmed. 2001. Population analysis of some agronomic and technological characteristics of upland cotton (Gossypium hirsutum L.). Pakistan J. Biol. Sci., 1:120-123.

USDA, United State Department Agriculture. 2021. Cotton and Products Annual Egypt Cotton Production Rebounds. Report Number: EG2021-0005; 1-17.

USDA-AMS. 1980. The classification of cotton. USDA Agric. Handb. 566. U.S. Gov. Print. Office, Washington, DC.

Wali, B. M. and V. R. Koraddi. 1989. Biometrical studies in rain fed cotton. Mansore J. Agric Sci., 23, pp.441-446.

Watts, D. B., G. B. Runion, K. W. Smith Nannenga, and H. A. Torbert. 2014. Enhanced-efficiency fertilizer effects on cotton yield and quality in the coastal plains. Agron. J., 106(2), pp.745-752. 